\title{
KORELASI PEMAHAMAN KETEKNIKAN DAN KEBERMAKNAAN PRAKTIKUM DENGAN LITERASI KEGURUAN TEKNIK MAHASISWA PTE UM
}

\author{
Miftahul Huda, \\ Setiadi Cahyono Putro, \\ Dwi Prihanto \\ Universitas Negeri Malang \\ E-mail: huda46883@gmail.com
}

\begin{abstract}
Abstrak
Penelitian ini untuk mengetahui hubungan secara simultan antara pemahaman keteknikan $\left(\mathrm{X}_{1}\right)$ dan kebermaknaan praktikum $\left(\mathrm{X}_{2}\right)$ dengan literasi keguruan teknik $(\mathrm{Y})$. Penelitian ini menggunakan rancangan penelitian deskriptif korelasional yang bersifat ex post facto. Subjek dalam penelitian ini adalah mahasiswa S1 PTE FT UM angkatan 2014 sejumlah 113 mahasiswa. Data tingkat pemahaman keteknikan adalah daftar nilai akhir (data sekunder), sedangkan data tingkat kebermaknaan praktikum diungkap dengan angket yang reliabilitasnya 0,728 (alpha cronbach's) dan data literasi keguruan teknik juga diungkap dengan angket yang reliabilitasnya 0,935 (alpha cronbach's). Analisis yang digunakan yaitu analisis regresi ganda. Dari uji hipotesis yang telah dilakukan dapat disimpulkan bahwa terdapat hubungan positif dan signifikan secara simultan antara tingkat pemahaman keteknikan dan tingkat kebermaknaan praktikum dengan literasi keguruan teknik.
\end{abstract}

Kata Kunci: literasi, keguruan, keteknikan, kebermaknaan, praktikum.

\begin{abstract}
The aims of this study is to know the correlation simultaneously between the understanding of engineering $\left(\mathrm{X}_{1}\right)$ and the practical significance $\left(\mathrm{X}_{2}\right)$ with engineering teacher training literacy $(\mathrm{Y})$. This study uses descriptive correlation study design which is ex post facto. Subject in this study is S1 students of PTE FT UM 2014 generation with number of 113 students. The data of engineering understanding is the list of final score (secondary data), while the data of practicum significance is revealed with the questionnaire which reliability 0,728 (alpha Cronbach) and engineering literacy data is also revealed with questionnaire which reliability 0,935 (alpha Cronbach). The analysis used is multiple regression analysis. From the hypothesis test that has been done can be concluded that there is a positive and significant correlation simultaneously between the understanding of engineering and the practical significance with engineering teacher training literacy.
\end{abstract}

Keywords: literacy, teacher, engineering, meaningfulness, practice.

\section{PENDAHULUAN}

Siswa SMK yang lahir pada rentangan tahun $1995 \mathrm{ke}$ atas sudah memasuki generasi Z. Yustisia mengungkapkan ciri-ciri generasi $\mathrm{Z}$ yaitu: (1) generasi digital, (2) mengutamakan media sosial, (3) cenderung toleran dengan perbedaan kultur dan sangat peduli dengan lingkungan, (4) terbiasa dengan berbagai aktifitas dalam satu waktu yang bersamaan, dan (5) kurang dalam berkomunikasi secara verbal, individualis, ingin serba instan, tidak sabaran, dan kurang menghargai proses. Sejalan dengan itu, dibutuhkan calon guru dengan kompetensi tinggi untuk menjadikan lulusan SMK yang berkualitas. Sebagai calon guru teknik, berliterasi merupakan salah satu cara untuk mendapatkan informasi sebagai bekal menjadi guru teknik yang berkualitas.

Berdasarkan hasil observasi dengan 34 mahasiswa Jurusan Teknik Elektro angkatan 2014 dan 2015, lebih dari $50 \%$ responden mengatakan selalu membaca buku pelajaran tetapi belum paham setiap selesai membaca buku pelajaran. Hal ini dapat dipastikan bahwa kemampuan literasi mahasiswa Jurusan Teknik Elektro masih kurang baik.

Disisi lain, meskipun sistem pendidikan Indonesia pada tahun 2012 sampai 2015 tercepat ke lima dari 72 negara ((OECD), 2016)Namun pada tahun 2012, hasil penelitian Programme for International Student Assessment (PISA) menyebutkan budaya literasi masyarakat Indonesia pada tahun 2012 terburuk kedua dari 65 negara yang di teliti di dunia. Indonesia menempati urutan ke 64 dari 65 negara tersebut dengan skor 375 ((OECD), 2016)

Literasi dalam istilah lain adalah kemelekan untuk membaca, namun secara umum tidak hanya membaca tapi juga menulis. Literasi adalah pernyataan sikap dari membaca, menulis dan berpikir untuk menciptakan sebuah konteks dalam sosio-kultural. Literasi juga tentang teks dan pembaca, siswa dan guru, kelas dan komunitas di lingkup lokal, regional dan internasional (Setiarini, 2016)). (Muthiah, 2014)menyatakan literasi 
tidak hanya 'melek huruf' secara literal, melainkan memahami dan menggunakan teks untuk dapat memanfaatkannya dalam berbagai situasi dan untuk mencapai berbagai tujuan.

Pada dasarnya, literasi mempunyai tiga unsur utama, yaitu: (1) membaca, (2) berpikir kritis, dan (3) menulis. Dalam bukunya (Rahayu, 2016)dijelaskan bahwa literasi merupakan suatu yang kontinum dari membaca, membaca dan menulis, serta membaca menulis dan berbahasa lisan. Sehingga membaca, menulis, berpikir kritis, dan berbahasa lisan dimanfaatkan untuk belajar sepanjang hayat baik di rumah, di tempat kerja maupun dalam masyarakat.

Membaca adalah proses pengolahan data secara kritis-kreatif yang dilakukan pembaca untuk memperoleh pemahaman menyeluruh tentang bacaan itu, yang diikuti oleh penilaian terhadap keadaan, nilai, fungsi, dan dampak bacaan itu (nurhadi, 2016)Tujuan dari membaca yaitu untuk mendapatkan informasi secara jelas, aktual, dan wawasan yang luas.

Berpikir kritis merupakan analisis situasi masalah melalui evaluasi potensi, pemecahan masalah, dan sintesis informal untuk menentukan keputusan (Kuswana, 2011)Tujuan dari berpikir kritis yaitu supaya individu dapat menelaah informasi dari teks yang telah di baca supaya memahami informasi tersebut.

Menulis merupakan proses menuangkan atau memaparkan informasi yang berupa pikiran, perasaan, atau kemauan dengan menggunakan wahana bahasa tulis berdasar-kan tataan tertentu sesuai dengan kaidah bahasa yang digunakan penulis (Ahmadi \& Supriyono, 1991) Seseorang dapat menulis jika sudah memahami suatu bacaan atau teks dengan cara berpikir kritis.

Menurut (Sari, 2016) Membaca, berpikir kritis, dan menulis merupakan tiga aktifitas yang saling berhubungan untuk mewujudkan sebuah proses belajar aktif yang bermakna. Kegiatan membaca, berpikir kritis, dan menulis merupakan solusi dalam mencari, menemukan, mengolah, dan memanfaatkan informasi, data dan ilmu pengetahuan. Kebiasaan membaca, berpikir kritis, dan menulis yang digabungkan akan meningkatkan kegiatan belajar mengajar yang aktif dan bermakna. Selain itu, akan membuat ilmu pengetahuan yang diterima tersimpan dalam memori otak individu secara sistematis, terstruktur dan masif.

Mahasiswa S1 PTE dituntut berliterasi di bidang profesi keguruan. Menurut (Rahmawati \& Suprihatiningrum, 2014), secara umum profesi guru memiliki karakteristik, yaitu: (1) komitmen; (2) berkompeten; dan (3) tanggung jawab. Jika karakteristik profesi guru terpenuhi, maka guru berhak mendapat-kan penghasilan, pengembangan profesi, jaminan perlindungan hukum, dan berhak dinaungi organisasi profesi.

Selain harus memiliki karakteristik seperti yang tertulis di atas, guru juga harus memenuhi standar profesi guru yang sudah di atur dalam UUGD No. 14/2005 Pasal 10 ayat 1 dan PP no.19/2005 Pasal 28 ayat 3, yaitu: (1) kompetensi pedagogik; (2) kompetensi kepribadian; (3) kompetensi sosial; dan (4) kompetensi profesional.
Menurut (Sopiatin, 2010)), kompetensi adalah kemampuan yang digunakan sebagai standar kinerja seseorang yang diharapkan dapat berkontribusi positif terhadap kinerja organisasi. Kompetensi mencakup tugas, keterampilan, sikap, dan apresiasi yang direfleksikan dalam kebiasaan berfikir dan bertindak dalam kehidupan sehari-hari. Menurut (Rahmawati \& Suprihatiningrum, 2014) kompetensi guru adalah hasil dari penggabungan kemampuan yang banyak jenisnya, dapat berupa seperangkat pengetahuan, keterampilan, dan perilaku yang harus dimiliki, dihayati, dan dikuasai oleh guru atau dosen dalam menjalankan tugas keprofesionalannya.

Menurut (Alawiyah, 2016)) mengarti-kan bahwa guru adalah pendidik profesional dengan tugas utama mendidik, mengajar, membimbing, mengarahkan, melatih, menilai, dan mengevaluasi peserta didik pada pendidikan anak usia dini jalur pendidikan formal, pendidikan dasar, dan pendidikan menengah. Sedangkan menurut (Jihad, 2013)menyatakan profesi guru tidak lebih daripada mendidik yang bermuatan bimbingan, binaan, asuhan, ataupun pengajaran.

Menjadi guru yang profesional tidak lepas dari keahlian yang harus dimiliki, yaitu; (1) pendidikan, (2) pelatihan, dan (3) pengalaman. Dalam bukunya (Jihad, 2013) menyatakan bahwa, menjadi guru profesional setidaknya memiliki standar minimal, yaitu; (1) memiliki kemampuan intelektual yang baik, (2) memiliki kemampuan memahami visi dan misi pendidikan, (3) memiliki keahlian mentransfer ilmu pengeta-huan kepada siswa secara efektif, (4) me-mahami konsep perkembangan psikologi anak, (5) memiliki kemampuan mengorganisasi proses belajar, dan (6) memiliki kreativitas dan seni mendidik. Sehingga, mahasiswa S1 PTE diharapkan mampu menjadi guru teknik yang profesional supaya mampu menghasilkan lulusan siswa SMK yang berkualitas.

Keguruan teknik sendiri yaitu segala hal yang berkenaan dengan pengajaran, pendidi-kan, dan metode pengajaran berdasarkan kemampuan pendidikan, pelatihan, dan pengalaman yang dimiliki di bidang keteknikan melalui pendidikan formal maupun informal. Sedangkan literasi keguruan teknik yaitu pengajaran, pendidikan, dan metode pengajaran yang akan diberikan kepada peserta didik berlandaskan informasi, pengetahuan keteknikan, kompetensi peda-gogik, kompetensi kepribadian, kompetensi sosial, dan kompetensi profesional.

Pemahaman keteknikan merupakan salah satu aspek dalam diri mahasiswa untuk menunjang menjadi guru yang profesional. Pemahaman keteknikan di Jurusan Teknik Elektro diindikasikan belum baik. Hal ini terbukti dari 55,9\% responden mengatakan setiap selesai kegiatan belajar mengajar masih kurang paham terhadap materi yang diajarkan. Selain itu, dalam hal tugas juga masih kurang baik. Hal ini dinyatakan dengan $73,5 \%$ responden tidak mengerjakan tugas secara mandiri. Bisa dikatakan mahasiswa tersebut mengerjakan tugas dengan menyontek tugas temannya. 
Menurut (Arif, 2014)menyatakan bahwa kemampuan teknik adalah salah satu keterampilan yang sangat perlu dimiliki oleh setiap individu dalam suatu organisasi dengan tujuan tercapainya sebuah kriteria yang diinginkan dalam sebuah organisasi tersebut. Sedangkan menurut (Handoko, 1985)kemampuan teknik merupakan salah satu kemampuan yang dimiliki manusia berupa keterampilan tertentu yang digunakan untuk melakukan suatu pekerjaan tertentu. (Gibson, Santoso, \& Mitchell, 2010)berkata lain bahwa keterampilan teknis adalah kemampuan untuk menggunakan alat-alat, prosedur dan teknik suatu bidang khusus.

Mengacu pada teori-teori tersebut, dapat diinterpretasikan bahwa kemampuan teknik adalah keterampilan tertentu yang harus dimiliki oleh setiap orang dengan tujuan untuk melakukan suatu pekerjaan tertentu dengan cara yang sudah ditentukan. Sehingga, pemahaman keteknikan adalah sebuah dasar seseorang baik dalam individu maupun kelompok untuk melakukan suatu tindakan berdasarkan pengalaman dengan tujuan mendapatkan keterampilan tertentu dari suatu proses pekerjaan.

Pemahaman keteknikan mahasiswa calon guru didapatkan ketika perkuliahan di kampus. Sebagaimana hasil pengetahuan dari perkuliahan tersebut telah didokumentasikan pada nilai akademik, dikhususkan pada matakuliah yang relevan dalam bidangnya untuk bekal sebagai calon guru teknik. Pemahaman keteknikan yang didapatkan oleh calon guru sudah tertulis dalam matukuliah keahlian berkarya Kurikulum Program Studi S1 Pendidikan Teknik Elektro FT UM 2014.

Jika pemahaman terhadap keteknikan tinggi, maka diharapkan berdampak positif pada kegiatan praktikum. Sehingga praktikum akan menjadi lebih bermakna. Praktikum yang berjalan di Jurusan Teknik Elektro khususnya prodi S1 PTE masih kurang dari kata bermakna. Penyebabnya adalah kurangnya unsur K3LH dan belum memperhatikan langkah kerja praktikum. Pernyataan tersebut dari 34 mahasiswa Jurusan Teknik Elektro angkatan 2014 dan 2015 melalui kritik dan saran di akhir observasi. Selain itu, kesadaran diri praktikan juga sangat dibutuhkan supaya kegiatan praktikum berjalan dengan lancar dan efisien. Sehingga, diharapkan dapat meningkatkan hasil praktikum yang lebih baik, tidak sekedar mendapat ilmu pengetahuan namun mendapat pengalaman praktikum yang bermanfaat dan bermakna.

Dalam bukunya (Ahmad Susanto, 2016)Ausubel menyatakan belajar bermakna merupakan suatu proses dikaitkannya informasi baru pada konsep-konsep yang relevan yang terdapat dalam struktur kognitif seseorang. (Majid, 2014)menyatakan belajar akan lebih bermakna jika anak me-ngalami langsung apa yang dipelajarinya dengan mengaktifkan lebih banyak indra daripada hanya mendengarkan orang atau guru menjelaskan.

Menurut (nurhadi, 2016)pembela-jaran bermakna merupakan pemahaman, relevansi dan penilaian pribadi sangat terkait dengan kepentingan siswa dalam mempelajari isi materi pelajaran. Pembelajaran di-rasakan terkait dengan kehidupan nyata atau siswa mengerti manfaat isi pembelajaran. Pembelajaran bermakna selain bisa mengaitkan pengeta-huan lama dengan pengetahuan baru, juga sangat penting bahwa dalam belajar siswa harus paham lebih dari sekedar tahu sehingga bisa menjawab apa-mengapa-bagaimana.

Berdasarkan uraian tersebut, indikator belajar bermakna yaitu proses belajar yang berhubungan dengan kehidupan nyata dengan dasar pengetahuan kognitif individu yang dikaitkan dengan pengetahuan yang baru supaya individu faham dengan manfaat belajar yang dilaksanakan. Adapun faktor-faktor yang dapat menggambarkan belajar bermakna yaitu: (1) adanya konsep belajar yang relevan pada pengetahuan sesorang, (2) seseorang mengalami langsung apa yag dipelajarinya, (3) siswa mengerti manfaat isi pembelajaran, dan (4) siswa paham lebih dari sekedar tahu.

Sedangkan praktikum adalah bagian dari pengajaran yang bertujuan agar peserta didik mendapat kesempatan untuk menguji dan melaksanakan dalam keadaan nyata apa yang di dapat dalam teori (Indonesia, 2005) (Mariyam, Lestari, \& Afniyanti, 2015)menyatakan bahwa praktikum merupakan salah satu bentuk kegiatan belajar mengajar yang dimaksudkan untuk memantapkan penguasaan materi yang bersifat aplikatif. (Sudirman \& Sucitra, 2010)menyatakan bahwa dalam kegiatan praktikum mahasiswa harus melakukan tiga tahapan yakni: persiapan praktikum, pelaksanaan praktikum, dan penyusunan laporan praktikum.

Sehingga kebermaknaan praktikum dapat diinterpretasikan sebagai proses belajar terstruktur dan sistematis yang berhubungan dengan kehidupan nyata dengan dasar pengetahuan kognitif individu. Pengetahuan yang lama dikaitkan dengan pengetahuan yang baru supaya individu paham dengan manfaat belajar yang dilaksanakan dengan tujuan untuk meningkatkan pemahaman dan penguasaan teori dari ilmu pengetahuan tertentu.

Adapun faktor-faktor dalam kebermak-naan praktikum, yaitu sebagai berikut: (1) individu mempunyai pengetahuan dasar; (2) adanya relevansi antara praktikum dengan kehidupan nyata; (3) praktikum yang dilaksanakan sudah terjadwal dan terstruktur; (4) individu paham akan materi yang dipraktikkan; dan (5) penilaian pribadi ke-pada setiap praktikan.

Berdasarkan uraian di atas, akan dikaji tentang korelasi pemahaman keteknikan dan kebermaknaan praktikum dengan literasi keguruan teknik mahasiswa Program Studi S1 PTE Jurusan Teknik Elektro Fakultas Teknik Universitas Negeri Malang. Sebelum mengungkap hubungan variabel bebas ter-hadap variabel terikat, penelitian ini di dahului dengan mengungkap deskripsi tingkat pemahaman keteknikan dan tingkat kebermaknaan praktikum, dan literasi keguruan teknik mahasiswa program studi S1 PTE Jurusan Teknik Elektro Fakultas Teknik Universitas Negeri Malang. 


\section{METODE PENELITIAN}

Penelitian ini menggunakan metode penelitian kuantitatif dengan rancangan deskriptif korelasional dan bersifat Ex Post Facto. Penelitian ini menggunakan rancangan deskriptif korelasional dengan tujuan mendeskripsikan variabel tingkat pemahaman keteknikan dan kebermaknaan praktikum dengan literasi keguruan teknik mahasiswa program studi S1 PTE Jurusan Teknik Elektro Fakultas Teknik Universitas Negeri Malang. Gambar 1 Merupakan skematik penelitian ini.

Populasi yang digunakan yaitu maha-siswa program studi S1 PTE Jurusan Teknik Elektro Fakultas Teknik Universitas Negeri Malang Angkatan 2014. Sampel ditentukan dengan teknik purposive sampling (sampel bertujuan). Menurut (Arikunto \& Suhardjono, 2006)purposive sampling dilakukan dengan cara mengambil subyek bukan didasarkan atas strata, random atau daerah tetapi didasarkan atas adanya tujuan tertentu. Pengambilan semua populasi untuk sampel bertujuan untuk didapatkan hasil dengan kesalahan yang kecil. Jumlah sampel yang digunakan yaitu sebanyak 113 mahasiswa.

Variabel literasi keguruan teknik dan tingkat kebermaknaan praktikum akan diungkap dengan menggunakan instrumen angket atau kuesioner dengan skala likert. Nilai alpha cronbach's hasil uji reliabilitas instrumen variabel kebermaknaan praktikum sebesar 0,728, sementara nilai alpha cronbach's hasil uji reliabilitas instrumen variabel literasi keguruan teknik sebesar 0,935 . Sedangkan untuk mengungkap tingkat pemahaman keteknikan mengguna-kan data sekunder. Data sekunder yang dimaksud yaitu berupa DNA (daftar nilai akhir) mata-kuliah keahlian berkarya sebanyak 23 mata-kuliah yang di dapat dari Subag Akademik Fakultas Teknik UM

Regresi ganda digunakan untuk menga-nalisis data penelitian ini. Tahap pertama yang dilakukan yaitu uji prasyarat analisis, ujinya yaitu: (1) uji normalitas, (2) uji linearitas, (3) uji multikolinearitas, (4) uji autokorelasi, dan (5) uji heteroskedastisitas. Hasil uji prasyarat analisis yang telah dilakukan telah memenuhi syarat untuk menggunakan statistik parametrik (lihat hasil dan pembahasan). Tahap kedua yaitu persiapan analisis regresi berbantuan aplikasi SPSS dengan memasukkan data yang lolos uji prasayarat. Tahap terakhir, yaitu mengo-lah data di aplikasi SPSS untuk memenuhi kebutuhan kebutuhan tujuan penelitian. Taraf signifikan yang digunakan pada penelitian ini yaitu sebesar 0,5 (p.sig $=5,00 \%)$.

\section{HASIL DAN PEMBAHASAN}

Mahasiswa program studi S1 PTE Jurusan Teknik Elektro Fakultas Teknik Universitas Negeri Malang memiliki tingkat pemahaman keteknikan yang cukup dengan jumlah 51 mahasiswa (45\%), sedangkan kategori tinggi sebanyak 24 mahasiswa (21\%). Lebih lengkapnya lihat Tabel 1.
Tabel 1. Distribusi Variabel Pemahaman Keteknikan

\begin{tabular}{lccc}
\hline Kategori & Interval (i) & f & \% \\
\hline Sangat Tinggi & $89,75-100,00$ & 0 & $0 \%$ \\
Tinggi & $82,25-88,75$ & 24 & $21 \%$ \\
Sedang & $74,75-81,25$ & 51 & $45 \%$ \\
Rendah & $67,25-73,75$ & 28 & $25 \%$ \\
Sangat Rendah & $40,00-66,25$ & 10 & $9 \%$ \\
\hline Total & & 113 & $100 \%$ \\
\hline
\end{tabular}

Mahasiswa program studi S1 PTE Jurusan Teknik Elektro Fakultas Teknik Universitas Negeri Malang memiliki tingkat pemahaman keteknikan yang cukup. Hal tersebut tertuang dalam daftar nilai akhir matakuliah Dasar Konversi Energi Listrik sebagai penyumbang nilai tertinggi dan matakuliah Matematika 3 sebagai penyumbang nilai paling rendah. Penelitian terdahulu oleh (Putro, 2016)menyatakan tingkat pe-ngetahuan keteknikan mahasiswa PTE FT UM angkatan 2012 sangat tinggi. Matakuliah yang berkontribusi nilai tinggi yaitu mata-kuliah Dasar Pemrograman Komputer, sedangkan nilai terendah dari matakuliah Elektronika Daya Lanjut. Dapat dibandingkan bahwa semakin pesatnya teknologi tidak menjamin dapat mening-katkan pengetahuan keteknikan mahasiswa S1 PTE FT UM.

Pemahaman keteknikan merupakan mo-dal pengetahuan secara teori untuk menjadi seorang guru di SMK. Pemahaman ketek-nikan di dapat mahasiswa ketika berada di bangku kuliah. Sebagai calon guru teknik, selain menyusun langkah-langkah pembela-jaran, mahasiswa juga dituntut untuk me-mahami materi yang akan diajarkan. Sehingga, siswa SMK mendapat pengetahuan teori yang optimal. Jika siswa SMK sudah memahami dengan benar pengetahuan ketek-nikan yang diajarkan oleh guru, maka siswa SMK dapat melakukan pekerjaan tertentu dengan cara yang sudah ditentukan di bidang keteknikan.

Pemahaman keteknikan merupakan salah satu kompetensi yang harus dimiliki maha-siswa Jurusan Teknik Elektro. Kompetensi tersebut harus diajarkan dengan benar kepada siswa SMK berdasarkan teori yang telah di dapat. Sehingga, lulusan SMK mendapat bekal kompetensi yang optimal ketika terjun ke dunia kerja/dunia industri. Menurut Setianingtyas dan (Putro, 2016)kompe-tensi merupakan hasil kemampuan siswa selama mengikuti proses belajar mengajar. Kompetensi yang dituju yaitu pada mata pelajaran produktif supaya relevan dengan tuntutan dan permintaan dunia kerja.

Pemahaman keteknikan dapat diketahui dari daftar nilai akhir yang diinterpretasikan melalui angka. Mahasiswa akan mengetahui hasil pemahaman keteknikan setelah menger-jakan tugas dan mengikuti proses belajar lainnya yang diberikan oleh dosen dengan waktu yang telah ditentukan. Setiap semester, mahasiswa dapat mengetahui tingkat pema-haman keteknikannya selama mengikuti perkuliahan. Hasil penelitian ini, diharapkan mahasiswa S1 PTE dapat meningkatkan pemahaman keteknikannya, karena tingkat pemahaman keteknikan mahasiswa S1 PTE masih dalam kategori sedang. 
Tabel 2 memaparkan tingkat kebermak-naan praktikum mahasiswa program studi S1 PTE Jurusan Teknik Elektro Fakultas Teknik Universitas Negeri Malang berada pada kategori tinggi dengan jumlah 70 mahasiswa (62\%). Sedangkan 7 mahasiswa (6\%) masuk dalam kategori sangat tinggi.

\section{Tabel 2. Distribusi Variabel Kebermaknaan} Praktikum

\begin{tabular}{lccc}
\hline Kategori & Interval (i) & $\mathbf{f}$ & $\mathbf{\%}$ \\
\hline Sangat Tinggi & $130-152$ & 7 & $6 \%$ \\
Tinggi & $107-129$ & 70 & $62 \%$ \\
Sedang & $84-106$ & 36 & $32 \%$ \\
Rendah & $61-83$ & 0 & $0 \%$ \\
Sangat Rendah & $38-60$ & 0 & $0 \%$ \\
\hline Total & & 113 & $100 \%$ \\
\hline
\end{tabular}

Mahasiswa program studi S1 PTE Jurusan Teknik Elektro Fakultas Teknik Universitas Negeri Malang memiliki tingkat kebermaknaan praktikum yang tinggi. Keber-maknaan praktikum merupakan proses belajar terstruktur dan sistematis yang ber-hubungan dengan kehidupan nyata dengan dasar pengetahuan kognitif individu. Dari 5 indikator yang telah dijabarkan dalam instru-men penelitian variabel tingkat kebermak-naan praktikum diketahui bahwa indikator informasi baru relevan dengan pengetahuan dasar individu mendapatkan nilai rata-rata tertinggi. Artinya, bahwa mahasiswa S1 PTE setiap melaksanakan praktikum selalu mendapatkan pengetahuan yang baru dan relevan dengan pengetahuan yang dimilikinya. Pe-ngetahuan baru tersebut bisa berupa teori, alat dan bahan, serta kegiatan praktikum itu sendiri. Sedangkan pengetahuan yang dimilikinya berasal dari matakuliah keahlian berkarya yang bukan praktikum.

Sedangkan indikator penilaian langsung kepada setiap individu berada paling bawah nilai rata-ratanya. Artinya, mahasiswa jarang mendapat informasi nilai yang ditunjukkan langsung kepada dirinya ketika praktikum. Hal tersebut diindikasikan dari nilai proses, nilai sikap, nilai hasil praktikum, dan nilai laporan. Sehingga mahasiswa kurang menge-tahui apakah praktikumnya dapat dikatakan baik atau kurang baik. Akibatnya mahasiswa kurang peduli dengan evaluasi pembelajaran pada dirinya sendiri.

Dalam penelitian ini nilai proses yaitu penilaian untuk mahasiswa ketika sedang melaksanakan praktikum, apakah prosesnya sudah benar atau belum. Sedangkan nilai sikap berdasarkan sikap mahasiswa ketika berlangsung, apakah banyak berguraunya atau tidak. Selanjutnya, nilai hasil praktikum berdasarkan keberhasilan praktikum yang dilakukan mahasiswa, apakah praktikumnya dikatakan berhasil atau gagal. Terakhir yaitu nilai laporan yang berdasarkan hasil laporan yang sudah dikerjakan, apakah laporannya sesuai praktikum atau masih perlu diperbaiki.

Praktikum sendiri merupakan model pembelajaran berbabis konstruktivis. Infor-masi baru yang diterima mahasiswa ketika praktikum harus mampu dipahami serta direlasikan dengan pengetahuan yang di-milikinya.
Karena kemampuan berfikir kritis sangat dibutuhkan dalam menunjang proses pembelajaran supaya lebih efektif. Indikator lain yang tertuang dalam variabel tingkat kebermaknaan praktikum yaitu relevansi praktikum dengan kehidupan nyata, individu paham materi yang dipraktikkan, dan prak-tikum terjadwal dan terstruktur.

Indikator relvansi praktikum dengan kehidupan nyata mendapat rata-rata tertinggi kedua setelah indikator informasi relevan dengan pengetahuan dasar individu. Karena, praktikum yang dilaksanakan selain berdasar pengetahuan yang dimiliki individu juga harus berdasarkan kejadian maupun penga-laman yang terjadi di kehidupan nyata. Sehingga, hal tersebut dapat meningkatkan kebermaknaan praktikum yang sedang dilak-sanakan. Indikator dengan peringkat ketiga yaitu individu paham materi yang diprak-tikkan. Selain dari dua indikator dengan nilai tertinggi, praktikum tidak akan berlanjut jika materi praktikum yang dilaksanakan tidak dipahami oleh praktikan. Jika individu sete-lah melakasanakan praktikum namun tetap tidak paham, maka dapat dikatakan bahwa praktikum tersebut belum bermakna.

Praktikum akan lebih tidak bermakna jika tidak adanya jadwal yang mengaturnya. Hal ini tertuang dalam indikator dengan peringkat keempat, yaitu praktikum terjadwal dan terstruktur. Terjadwal artinya praktikum yang dilaksanakan mempunyai jumlah perte-muan yang sesuai dengan banyak atau sedi-kitnya materi yang akan dipraktikkan. Sedangkan terstruktur artinya materi yang akan dipraktikan mampu berurutan dari mudah sampai sulit. Jika semua indikator di atas sudah berjalan dengan efektif, maka praktikum yang bermakna dapat dicapai dengan mudah.

Tabel 3 memaparkan literasi keguruan teknik mahasiswa program studi S1 PTE Jurusan Teknik Elektro Fakultas Teknik Universitas Negeri Malang berada pada kategori sangat tinggi dengan jumlah 62 mahasiswa $(55 \%)$. Sedangkan 48 mahasiswa $(42 \%)$ berada pada kategori tinggi, 3 mahasiswa (3\%) berada pada kategori sedang, dan tidak ada mahasiswa masuk dalam kategori rendah sampai sangat rendah.

\section{Tabel 3. Distribusi Variabel Literasi Keguruan Teknik}

\begin{tabular}{lccc}
\hline Kategori & Interval (i) & f & \% \\
\hline Sangat Tinggi & $130-152$ & 62 & $55 \%$ \\
Tinggi & $107-129$ & 48 & $42 \%$ \\
Sedang & $84-106$ & 3 & $3 \%$ \\
Rendah & $61-83$ & 0 & $0 \%$ \\
Sangat Rendah & $38-60$ & 0 & $0 \%$ \\
\hline Total & & 113 & $100 \%$ \\
\hline
\end{tabular}

Mahasiswa program studi S1 PTE Jurusan Teknik Elektro Fakultas Teknik Universitas Negeri Malang memiliki literasi keguruan yang sangat tinggi. Literasi keguruan teknik merupakan pengajaran, pendidikan, dan metode pengajaran yang akan diberikan kepada peserta didik berlandaskan informasi, pengetahuan ketek-nikan, kompetensi pedagogik, kompetensi kepribadian, 
kompetensi sosial, dan kom-petensi profesional. Berdasarkan hasil pe-nelitian yang telah dilakukan, didapatkan bahwa lebih dari sebagian mahasiswa S1 PTE berada pada literasi keguruan teknik yang sangat tinggi. Artinya, bahwa mahasiswa S1 PTE sangat mengetahui hal-hal yang harus dilakukan ketika menjadi guru teknik di SMK. Selain itu, mahasiswa juga sudah mengetahui modal apa saja yang harus di-penuhi untuk menjadi guru teknik di SMK.

Dari 4 indikator yang telah dijabarkan dalam instrumen penelitian ini, didapatkan indikator literasi kepribadian yang men-dapatkan nilai rata-rata sangat tinggi. Artinya, bahwa mahasiswa S1 PTE mampu berkepribadian selayaknya guru teknik di SMK. Dari mulai berperilaku dan beretika, me-ngendalikan emosi, menjaga wibawa, men-jadi teladan, sampai berakhlak mulia. Karena dengan berperilaku dan beretika yang benar dan sopan, akan membuat siswa SMK lebih menghargai gurunya. Selain itu, guru yang mampu mengendalikan emosinya dapat me-numbuhkan komunikasi yang baik antara siswa dengan guru. Sehingga, tanpa disadari guru tersebut telah menjaga wibawanya dihadapan siswa. Tentu saja, hal ini dapat menjadi teladan bagi rekan-rekan guru, siswapun juga akan mencontoh keteladanan guru tersebut. Karena, guru yang berperilaku demikian tentunya memiliki akhlak yang mulia.

Indikator literasi sosial mendapat nilai rata-rata tertinggi kedua setelah indikator literasi kepribadian. Literasi sosial meru-pakan bagaimana caranya setiap individu dapat berkomunikasi dengan sesama teman, anak didik, atasan, maupun warga sekitar. Seseorang belum dapat dikatakan pribadi yang sempurna jika kurang bersosialisasi kepada orang lain. Karena, kepribadian yang menilai bukan diri sendiri tetapi orang lain.

Indikator dengan nilai rata-rata tertinggi ketiga yaitu indikator literasi profesional. Menjadi guru SMK tidaklah semudah yang dibayangkan. Salah satu kompetensi pendu-kungnya yaitu keprofesionalitasan seorang guru. Seorang guru harus mempunyai kualifikasi akademik dan latar belakang pen-didikan sesuai dengan bidangnya. Seorang guru harus memahami prosedur mengajar yang diterapkan di suatu SMK. Seorang guru dituntut dapat bertanggung jawab terhadap pelaksanaan tugas keprofesionalannya. Seo-rang guru harus bersedia mengembangkan keprofesionalannya secara berkelanjut de-ngan belajar sepanjang hayat. Selain empat hal tersebut, sebagai seorang guru harus memiliki komitmen untuk meningkatkan mutu pendidikan, keimanan, ketakwaan, dan akhlak mulia.

Sedangkan indikator literasi pedagogik mendapatkan nilai rata-rata paling rendah dari semua indikator. Dapat dikatakan bahwa calon guru yang mempunyai model pem-belajaran yang efektif, mempunyai kemam-puan intelektual yang baik, memiliki krea-tifitas mendidik, dan memiliki panggilan jiwapun belum tentu mampu menjadi guru teknik yang diharapkan siswa SMK. Karena, karakteristik siswa SMK di Indonesia sangatlah beragam. Oleh karena itu, jika calon guru tidak memamahami karakteristik siswa dan sekolah, maka sulit menjadi guru yang berkualitas. Sehingga, diharapkan mahasiswa S1 PTE dapat menentukan sekolah mana yang akan ia ajar supaya proses pembelajaran berjalan efektif dan efisien. Dari indikator-indikator yang sudah tertuang dalam variabel penelitian ini, diharapkan mahasiswa S1 PTE dapat memahami kompetensi-kompetensi yang harus dikem-bangkan sebagai calon guru di SMK.

Hasil uji normalitas yang telah diperoleh pada variabel X1, X2, dan Y bernilai (p) secara urut yaitu sebesar 0,$145 ; 0,497$; dan 0,797 . Nilai (p) tiga variabel tersebut di atas 0,05 , sehingga dapat dikatakan data berdistribusi normal.

Hasil uji linearitas yang telah dilakukan didapatkan nilai signifikansi (X1 dan $\mathrm{Y}$ serta $\mathrm{X} 2$ dan $\mathrm{Y}$ ) di bawah 0,05. Sehingga hubungan $X 1$ dan $Y$ serta $X 2$ dan $Y$ dinya-takan linear.

Uji multikolinearitas yang telah dila-kukan didapatkan hasil nilai Tolerance $>0,1$ dan VIF $<10$. Sehingga dapat dikatakan hubungan antar variabel bebas tidak terjadi multikolinearitas.

Uji autokorelasi menggunakan uji run test dengan taraf signifikansi 0,05. Hasil yang didapatkan dari uji run test yaitu nilai Asymp. Sig. (2-tailed) 0,395. Karena nilai Asymp. Sig. (2-tailed) lebih besar dari 0,05, sehingga dapat dikatakan tidak terjadi autokorelasi.

Hasil pengujian hipotesis yang telah dilakukan terhadap variabel pemahaman keteknikan dengan literasi keguruan teknik diketahui positif dan signifikan dengan nilai $\mathrm{r}=0,550$ (Phitung $=0,00<0,05$ ). Hasil perhitungan yang telah dilakukan meng-hasilkan sumbangan relatif sebesar 36,85\%. Sedangkan sumbangan efektifnya sebesar $12,27 \%$.

Pemahaman keteknikan merupakan kom-petensi dalam bidang ilmu pengetahuan yang harus dicapai oleh mahasiswa dalam per-kuliahan. Pemahaman keteknikan merupakan aspek kognitif yang harus dilatih oleh mahasiswa. Pemahaman keteknikan yang tinggi akan menunjang efektifitas kegiatan pembelajaran di kelas. Sehingga, akan men-ciptakan kondisi belajar yang diharapkan mahasiswa. Karena kondisi belajar tidak hanya diciptakan dari faktor luar individu saja, tetapi juga dari dalam individu tersebut.

Jika mahasiswa sudah memiliki pema-haman keteknikan yang tinggi dan mampu mengembangkannya, maka diharapkan mam-pu menjadi guru di SMK yang berkualitas. Pengetahuan sangat dibutuhkan untuk mencetak guru yang berkualitas. Karena untuk menjadi guru harus memenuhi empat kompetensi, salah satunya yaitu kompetensi profesional. Pemahaman ketek-nikan ada kaitannya dengan kompetensi profesional yang harus dimiliki guru. Se-hingga, mahasiswa harus mencari informasi bagaimana menjadi guru dengan memiliki kompetensi profesional yang tinggi. Kom-petensi profesional sendiri sudah masuk dalam indikator variabel literasi keguruan teknik yaitu literasi profesional. Namun, indikator literasi profesional berada pada urutan ketiga jumlah nilai rata-ratanya dalam variabel literasi keguruan teknik. 
Meskipun berada diurutan ketiga pada indikator variabel literasi keguruan teknik, bukan berarti bahwa literasi profesional diabaikan saja. Tetapi sebaliknya, dengan indikator literasi profesional yang lemah diharapkan mahasiswa dapat meningkat-kannya. Hal tersebut akan berdampak pada kesiapannya menjadi guru. Seorang guru SMK akan lebih percaya diri dalam mengajar ketika memiliki pengetahuan ketkenikan yang tinggi. Selaini itu, dengan pemahaman keteknikan yang tinggi, siswa mendapatkan bekal pengetahuan yang optimal. Pemahaman keteknikan yang diajarkan guru akan lebih baik jika sejalan dengan dunia usaha/dunia kerja yang akan ditekuni siswa.

Sumbangan relatif pemahaman ketekni-kan lebih rendah dibandingkan sumbangan relatif kebermaknaan praktikum terhadap literasi keguruan teknik. Hasil ini sejalan dengan penelitian (Putro, 2016)yang menyatakan bahwa sumbangan relatif pengetahuan keteknikan terhadap kemam-puan adaptasi calon guru sebesar 2,00\%. Dapat diindikasikan bahwa untuk menjadi guru SMK modal utama bukanlah penge-tahuan keteknikan, namun dari faktor lain. Meskipun demikian, pemahaman keteknikan yang dimiliki mahasiswa masih berhubungan dan berpengaruh pada literasi keguruan teknik mahasiswa S1 PTE. Jika semakin tinggi pemahaman keteknikan yang dimiliki mahasiswa, maka literasi keguruan tekniknya juga akan meningkat. Sehingga, diharapkan mahasiswa S1 PTE dapat meningkatkan pemahaman keteknikannya sebagai bekal menjadi guru. Selain itu, dapat juga meningkatkan literasi pedagogiknya untuk menjadi guru, karena indikator tersebut berada paling rendah nilai rata-ratanya.

Hasil pengujian hipotesis yang dilakukan terhadap variabel kebermaknaan praktikum degan literasi keguruan teknik juga diketahui positif dan signifikan dengan nilai $r=0,540$ (Phitung $=0,00<0,05$ ). Hasil perhitungan yang telah dilakukan menghasilkan sumbangan relatif sebesar $63,15 \%$. Sedangkan sumbangan efektifnya sebesar $21,03 \%$.

Kebermaknaan praktikum merupakan proses belajar terstruktur dan sistematis yang berhubungan dengan kehidupan nyata dengan dasar pengetahuan kognitif individu. Pene-litian (Ariyati, 2010)mengatakan bahwa dengan pembelajaran berbasis praktikum da-pat meningkatkan kemampuan berfikir kritis mahasiswa. Berfikir kritis merupakan salah satu dasar kemampuan berliterasi. Jika maha-siswa mampu berfikir kritis, maka mahasiswa sudah memenuhi salah satu unsur utama berliterasi. Konteks berifikir kritis disini yaitu dalam kegiatan praktikum, sedangkan literasi yang dituju yaitu literasi keguruan teknik. Sehingga, diharapkan mahasiswa yang me-laksanakan praktikumnya dirasa bermakna dapat meningkatkan literasi keguruan tekniknya.

Kebermaknaan praktikum merupakan pembelajaran yang bersifat kontruktivisme. Pengetahuan yang baru dapat dikontruksikan dalam pikirannya. Sehingga, pengetahuan baru dapat diintegrasikan ke dalam pengetahuan kognitif individu, serta dapat diterap-kan dalam kehidupan khususnya menjadi ca-lon guru teknik di
SMK. Kebermaknaan praktikum sangat disumbang tinggi oleh indikator informasi baru relevan dengan pengetahuan dasar indvidu. Dimana ketika seseorang mendapat informasi baru, dia sudah dinyatakan berliterasi. Sehingga, mahasiswa yang melaksanakan praktikum dengan materi/teori baru sangat berhubungan dan mempengaruhi literasi keguruan teknik-nya.

Informasi baru relevan dengan penge-tahuan dasar individu disini berkaitan dengan tujuan praktikum yang menguji dan melak-sanakan teori dan materi praktikum sebelum-nya harus berkaitan dengan materi praktikum selanjutnya. Selain itu diharapkan adanya kesinambungan antara teori dan praktik sehingga dalam pengaplikasiannya dapat berjalan dengan lancar. Misal, teori cara menggunakan alat dan bahan praktikum, disini mahasiswa dituntut ketepatannya dalam penggunan alat dan praktikum ketika sedang praktikum berlangsung. Jika dalam penggu-naan alat dan praktikum tersebut sudah benar, maka teori tersebut mampu dibuktikan dan diharapkan dapat menjadi bekal ketika mengajar di SMK.

Adapun indikator dengan peringkat kedua dari setiap variabel yang saling ber-hubungan antara variabel kebermaknaan praktikum dengan literasi keguruan teknik. Indikator variabel tingkat kebermaknaan praktikum urutan kedua yaitu relevansi praktikum dengan kehidupan nyata. Sedang-kan indikator variabel literasi keguruan tek-nik urutan kedua yaitu literasi sosial. Kedua indikator tersebut sama-sama menginterpre-tasikan lingkungan sekitar. Relevansi prakti-kum dengan kehidupan nyata berisikan mate-ri praktikum yang sesuai dengan kehidupan sehari-hari, sehingga hasil praktikum mampu diterapkan dalam kehidupan nyata. Sama halnya dengan literasi sosial, bahwa guru dituntut mampu bergaul dan komunikasi dengan siswanya terlebih dahulu, kemudian diharapkan dapat bergaul dan komunikasi dengan masyarakat sekitar.

Indikator masing-masing variabel yang urutannya terakhir juga saling berhubungan. Indikator variabel tingkat kebermaknaan praktikum yang urutannya terakhir yaitu penilaian langsung kepada setiap individu. Sedangkan indikator variabel literasi kegu-ruan teknik yang urutannya terakhir yaitu literasi pedagodik. Hubungannya yaitu jika dalam pelaksanaan praktikum mahasiswa kurang mendapat informasi nilai, bisa jadi literasi pedagogik di bidang evaluasi juga rendah. Rendahnya evaluasi pembelajaran oleh guru, akan mengakibatkan siswa kurang memperhatikan proses belajarnya, sehingga siswa kurang mengerti hasil dari pembe-lajaran apakah sudah baik apa belum.

Dapat diindikasikan dari indikator-indi-kator yang terdapat pada masing-masing variabel, bahwa variabel kebermaknaan prak-tikum berhubungan dan berpengaruh terha-dap variabel literasi keguruan teknik. Artinya, jika kebermaknaan praktikum meningkat ma-ka literasi keguruan tekniknya juga mening-kat. 


\section{Tabel 4. Ringkasan Hasil Analisis Regresi Ganda}

\begin{tabular}{lc}
\hline Varabel Bebas & Sig. $t$ \\
\hline $\mathrm{X}_{1}$ & 0,000 \\
$\mathrm{X}_{2}$ & 0,000 \\
$\mathrm{R}$ & 0,577 \\
$\mathrm{R}$ Square & 0,333 \\
F hitung & 27,419 \\
Sig. F & 0,000 \\
\hline
\end{tabular}

Berdasarkan Tabel 4 diketahui bahwa nilai signifikansi $\mathrm{F}$ sebesar $0,000<0,05$, sehingga dapat dikatakan hubungan antara variabel pemahaman keteknikan dan keber-maknaan praktikum dengan literasi keguruan teknik secara simultan adalah linear dan signifikan.

Kebermaknaan praktikum lebih berpe-ngaruh terhadap literasi keguruan teknik daripada pemahaman keteknikan. Sejalan dengan penelitian Subagyo (2017) yang menyatakan bahwa ada pengaruh positif dan signifikan antara pengetahuan tentang ilmu keteknikan terhadap kesiapan menjadi guru SMK. Sehingga, erat sekali hubungannya antara pemahaman keteknikan dengan literasi keguruan teknik. Sedangkan penelitian rele-van yang mendukung variabel kebermaknaan praktikum dengan literasi keguruan teknik telah diteliti oleh (Ariyati, 2010)Kesimpulannya yaitu bahwa terdapat hubungan dan signifikan antara pembelajaran ekosistem dan keanekaragaman hayati melalui pembelajaran berbasis praktikum dengan kemampuan berfikir kritis. Sehingga, dapat dikatakan terdapat hubungan positif dan signifikan antara tingkat kebermaknaan praktikum dengan literasi keguruan teknik.

Pemahaman keteknikan dan kebermak-naan praktikum berhubungan dan berpenga-ruh terhadap literasi keguruan teknik maha-siswa S1 PTE. Hasil penelitian yang telah didapat menyatakan bahwa kedua variabel bebas tersebut memiliki hubungan positif dan signifikan secara simultan terhadap literasi keguruan teknik. Sehingga, apabila pemaha-man keteknikan dan kebermaknaan prakti-kum meningkat, maka literasi keguruan tek-nik mahasiswa S1 PTE juga mengalami peningkatan.

Pemahaman keteknikan merupakan dasar pemikiran seseorang untuk melakukan ke-giatan tertentu. Kegiatan disini yaitu prak-tikum yang dilakasanakan dengan bermakna. Sebagai mahasiswa, pemahaman keteknikan didapat lebih awal dibandingkan melaksana-kan praktikum. Pemahaman keteknikan yang baik dapat menciptakan situasi praktikum yang baik pula. Kegiatan praktikum yang dilaksanakan mahasiswa S1 PTE tidak jarang teori yang didapat di kelas kurang men-dukung. Sehingga, diharapkan mahasiswa S1 PTE dapat mencari teori sendiri diluar jam kuliah. Mencari informasi termasuk bagian dari literasi, dan diharapkan dapat mening-katkan literasi di bidang lainnya. Ada 4 indikator dalam variabel literasi keguruan teknik yaitu literasi pedagogik, literasi kepribadian, literasi sosial, dan literasi profesional. Jika mahasiswa mampu mendapatkan informasi tentang teori keteknikan, diharapkan mampu juga diterapkan dalam praktikum, sehingga dapat meningkatkan literasi keguruan tekniknya.

Kerangka berfikir dan pembahasan yang telah dijabarkan pada bab sebelumnya men-gatakan bahwa untuk meningkatkan literasi keguruan teknik, mahasiswa harus memper-hatikan pemahaman keteknikan dan keber-maknaan praktikum. Literasi keguruan teknik yang baik bisa juga didapat dari informasi maupun pengalaman lain di luar sistem per-kuliahan. Namun, literasi keguruan teknik yang tanpa didukung dengan pemahaman keteknikan yang baik, akan mempersulit mahasiswa itu sendiri ketika menjadi guru di SMK. Selain itu, memiliki pemahaman ketek-nikan yang baik masih kurang tanpa adanya dukungan dari praktikum yang bermakna. Literasi keguruan teknik akan optimal jika didukung dengan pemahaman keteknikan dan dipraktikkan secara bermakna.

\section{PENUTUP \\ Simpulan}

Pemahaman keteknikan mahasiswa pro-gram studi S1 PTE TE FT UM termasuk da-lam kategori sedang. Kebermaknaan prak-tikum mahasiswa program studi S1 PTE TE FT UM termasuk dalam kategori tinggi. Indikator yang sangat mendukung yaitu informasi baru relevan dengan pengetahuan dasar individu. Literasi keguruan teknik mahasiswa program studi S1 PTE TE FT UM termasuk dalam kategori sangat tinggi. Indikator yang sangat mendukung yaitu lite-rasi kepribadian.

Terjadi hubungan yang positif dan signifikan secara parsial antara pemahaman keteknikan dengan literasi keguruan teknik. Terjadi hubungan yang positif dan signifikan secara parsial antara kebermaknaan praktikum dengan literasi keguruan teknik. Sedang-kan secara simultan terdapat hubungan yang kuat antara pemahaman keteknikan dan kebermaknaan praktikum dengan literasi keguruan teknik.

\section{Saran}

Berdasarkan temuan pada penelitian ini, yang mengungkap hubungan antara pemaha-man keteknikan dan kebermaknaan prakti-kum dengan literasi keguruan teknik maha-siswa program studi S1 PTE TE FT UM, direkomendasikan beberapa saran terkait variabel yang diteliti. Pertama, karena hasil penelitian menunjukkan nilai terendah pema-haman keteknikan yaitu 40,02, sehingga diharapkan bagi dosen bisa menerapkan model pembelajaran yang dapat mening-katkan motivasi belajar mahasiswa. Kedua, karena hasil penelitian menunjukkan nilai rata-rata terendah terdapat pada indikator penilaian langsung kepada setiap individu pada variabel kebermaknaan praktikum, sehingga diperlukan lembar penilaian prakti-kum secara kompleks oleh dosen/asisten dosen supaya mahasiswa mengetahui nilai hasil praktikum dan menjadi acuan untuk evaluasi dirinya. Ketiga, dibutuhkan adanya penelitian lanjutan untuk 
mengungkap literasi keguruan teknik mahasiswa S1 PTE TE FT UM dengan menghadirkan variabel prediktor lain.

\section{DAFTAR PUSTAKA}

(OECD), O. for E. C. and D. (2016). PISA 2015 results in focus.

Ahmad Susanto, M. P. (2016). Teori Belajar dan Pembelajaran di Sekolah Dasar. Jakarta: Kencana.

Ahmadi, H. A., \& Supriyono, W. (1991). Psikologi Belajar. Jakarta: Rineka Cipta.

Alawiyah, F. (2016). Peran Guru dalam Kurikulum 2013. Jurnal Aspirasi, 4(1), 65-74.

Arif, M. S. (2014). Organisasi dan Manajemen. Jakarta: Universitas Terbuka.

Arikunto, S., \& Suhardjono, S. (2006). Penelitian tindakan kelas. Jakarta: Bumi Aksara.

Ariyati, E. (2010). Pembelajaran Berbasis Praktikum Untuk Meningkatkan Kemampuan Berpikir Kritis Mahasiswa. Jurnal Matematika Dan IPA, 1(2), 111.

Gibson, R. L., Santoso, Y., \& Mitchell, M. H. (2010). Bimbingan dan Konseling. Pustaka Pelajar.

Handoko, T. H. (1985). Manajemen Personalia dan Sumberdaya Manusia. Penerbit Liberty.

Indonesia, K. B. B. (2005). Departemen Pendidikan Nasional. Jakarta: Balai Pustaka.

Jihad, A. (2013). Menjadi Guru Profesional: Strategi Meningkatkan Kualifikasi dan Kualitas Guru di Era Global. Penerbit Erlangga.

Kuswana, W. S. (2011). Taksonomi Berpikir. Bandung: PT Remaja Rosdakarya.

Majid, A. (2014). Pembelajaran Tematik Terpadu. Bandung: PT Remaja Rosdakarya.

Mariyam, S., Lestari, R., \& Afniyanti, E. (2015). Analisis Pelaksanaan Praktikum Pada Pembelajaran Biologi Siswa Kelas VIII Di SMP Negeri 3 Kuntodarussalam Tahun Pembelajaran 2014/2015. Jurnal Ilmiah Mahasiswa FKIP Prodi Biologi, 1(1).

Muthiah, R. (2014). A Study On The Remediation Of Disorders In The Speaking Ability Of The Slow Learners In VI Standard Taught Under Activity Centred Teaching Of English. IOSR Journal of Research \& Method in Education, 4(6), 1-9.
Nurhadi. (2016). Teknik Membaca. Bandung: Bumi Aksara.

Putro, S. C. (2016). Pengetahuan Pedagogik dan Keteknikan Sebagai Prediktor Kemampuan Adaptasi Calon Guru Pada Mahasiswa Jurusan Teknik Elektro FT UM. Teknologi Dan Kejuruan, 39(1).

Rahayu, T. (2016). Penumbuhan Budi Pekerti Melalui Gerakan Literasi Sekolah. Malang: Muhammadiyah University Press.

Rahmawati, G., \& Suprihatiningrum, J. (2014). Pengaruh Model Pembelajaran Kooperatif Tipe Make A Match Terhadap Nilai Kerjasama Dan Hasil Belajar Kognitif Kimia Siswa Kelas X SMAN 1 Bambanglipuro Bantul. Jurnal Kaunia, 10(2), 128-140.

Sari, M. I. (2016). Pemetaan Kemampuan Literasi Mahasiswa Tingkat Awal Universitas Negeri Malang. SKRIPSI Jurusan Sastra IndonesiaFakultas Sastra UM.

Setiarini, S. (2016). The Use Of Literacy-Instructional Category To Improve Students'reading Comprehension. Vision: Journal for Language and Foreign Language Learning, 5(1), 149-168.

Sopiatin, P. (2010). Manajemen belajar berbasis kepuasan siswa. Bogor: Ghalia Indonesia.

Sudirman, M., \& Sucitra, A. (2010). Perilaku Mahasiswa Jurusan Pendidikan MIPA dalam Kegiatan Praktikum pada Fakultas Keguruan dan Ilmu Pendidikan Universitas Terbuka di UPBJJUT Bandung Masa Registrasi 2010.1. 